\title{
Estimating sex ratios in Caribbean hawksbill turtles: testosterone levels and climate effects
}

\author{
Lucy A. Hawkes ${ }^{1,2}$, Andrew McGowan ${ }^{1}$, Brendan J. Godley ${ }^{1}$, Shannon Gore ${ }^{3}$, \\ Anke Lange ${ }^{4}$, Charles R. Tyler ${ }^{4}$, Damon Wheatley ${ }^{5}$, Jim White ${ }^{5}$, Matthew J. Witt ${ }^{1}$, \\ Annette C. Broderick ${ }^{1, *}$ \\ ${ }^{1}$ Centre for Ecology \& Conservation, College of Life and Environmental Sciences, University of Exeter, Cornwall Campus, \\ Penryn, Cornwall TR10 9EZ, UK \\ ${ }^{2}$ School of Biological Sciences, Brambell Laboratories, Bangor University, Deiniol Road, Bangor, Gwynedd LL57 2 UW, UK \\ ${ }^{3}$ Conservation and Fisheries Department, Ministry of Natural Resources and Labour, PO Box 3323, Road Town, Tortola, \\ British Virgin Islands \\ ${ }^{4}$ Biosciences, College of Life and Environmental Sciences, University of Exeter, Stocker Road, Exeter EX4 4QD, UK \\ ${ }^{5}$ The Settlement, Anegada, British Virgin Islands
}

\begin{abstract}
Evolutionary theory predicts that male and female offspring should be produced at a 1:1 ratio, but this may rarely be the case for species in which sex is determined during incubation by temperature, such as marine turtles. Estimates of primary sex ratio suggest that marine turtle sex ratios are highly skewed, with up to 9 females per male. We captured juvenile hawksbill turtles Eretmochelys imbricata in waters around Anegada, British Virgin Islands, a regionally important foraging aggregation, and analysed concentrations of plasma testosterone and oestradiol-17 $\beta$ from 62 turtles to estimate sex ratio. There were 2.4 to 7.7 times more females than males. Testosterone concentrations correlated with sampling date and sea surface temperature (SST), with higher concentrations in the late summer when SST was highest, suggesting that assigning sex through threshold values of sex hormones must be carried out cautiously. The sex ratio in the juvenile foraging aggregation around Anegada is more male biased than at other locations, suggesting that turtles at Anegada have resilience against feminising effects of climate change. Future work should (1) integrate the relative contributions of different genetic stocks to foraging aggregations and (2) investigate the annual and seasonal cycles of sex hormones, and differences among individuals and life history stages.
\end{abstract}

KEY WORDS: Marine turtles $\cdot$ Sex ratio $\cdot$ Climate change $\cdot$ Hormones

\section{INTRODUCTION}

Evolutionary theory (Fisher 1930) suggests that male and female offspring should be produced in equal ('Fisherian') proportions. There should be selective pressure for this to be the case, because if one sex became rarer, that sex would have proportionally more opportunities to reproduce and would therefore contribute a higher proportion of offspring to the gene pool. The benefit of being the rarer sex should con- tinue until the sex ratio reaches 1:1, an 'evolutionary stable strategy' (Smith \& Price 1973). In genetic sex determination systems (GSD), the parental sex chromosomes recombine in a predictable way to produce a roughly balanced sex ratio. In environmental sex determination systems (ESD), however, the sex ratio depends on environmental conditions (e.g. temperature or photoperiod) during embryo incubation and thus often produces sex ratios that are highly skewed (Janzen \& Phillips 2006). 
Skewed sex ratios may be advantageous under specific biological circumstances (e.g. if parental investment in the sexes is unequal, if one sex helps their parents or if male siblings compete for mates), but also in some environmental circumstances (Warner \& Shine 2008). The Charnov-Bull model (Charnov \& Bull 1977) was proposed to explain this and has been demonstrated for a lizard species, such that offspring raised in conditions that promote high fitness for females had higher lifetime reproductive success if they were female than male (males were produced by hormonal manipulation at temperatures that usually lead to the development of females; Warner \& Shine 2008).

\section{Temperature-dependent sex determination}

In marine turtles, sex is determined by the temperature experienced during the middle third of the embryo incubation period (temperature-dependent sex determination [TSD], a type of ESD), where males are produced at lower temperatures and females at higher temperatures (Yntema \& Mrosovsky 1980, 1982, Mrosovsky 1988). The majority of research into sex ratios of marine turtles has been carried out on the nesting beach at the hatchling stage, and approaches using the modelled relationship between incubation temperature and sex ratio, as well as incubation duration and sex ratio, have enabled estimation of 'primary' sex ratio for a large number of rookeries (reviewed in Hawkes et al. 2009). Primary sex ratios vary among beaches and within clutches, as well as during the course of a nesting season, but are female-biased at almost all rookeries (Hawkes et al. 2009). Whether primary sex ratios remain femalebiased in later life stages ('secondary sex ratios') is not well understood, for several reasons: (1) juvenile marine turtles and adult male turtles remain almost exclusively in the ocean, where they are difficult to survey; (2) marine turtles are highly migratory (Godley et al. 2008) and thus are rarely located close to their natal area, where the primary sex ratio may be known; and (3) foraging aggregations appear to be comprised of mixed genetic stocks (Bass 1999, Diaz-Fernandez et al. 1999, Bowen et al. 2007, Mortimer et al. 2007, Blumenthal et al. 2009, Browne et al. 2010). Female-biased primary sex ratios may be maintained at later life stages (Kichler et al. 1999, Jensen et al. 2006, Theissinger et al. 2009, Hays et al. 2010, Joseph \& Shaw 2011), although some studies suggest that they are not (Wibbels et al. 1993, Diez \& Van Dam 2003).

\section{Population characteristics}

Of the 7 species of marine turtles, hawksbill sea turtles Eretmochelys imbricata are among the least well understood. International trade was once the major threat to hawksbill turtles, due to demand for 'tortoiseshell' products. Harvesting has now largely ceased but for a few Caribbean nations (Moncada et al. 2012), including the British Virgin Islands (BVI), where they are still legally harvested for subsistence purposes (Richardson et al. 2006). Approximately 25 to 75 hawksbill turtles nest in BVI annually, the majority on Anegada (Fletemeyer 1984, Hastings 1992), a remnant of a once larger population (McGowan et al. 2008). In contrast, the foraging aggregation of immature hawksbill turtles in the waters of the BVI is regionally significant, with the majority occupying the waters around Anegada (McGowan et al. 2008, Witt et al. 2010a) (see our Fig. 1), which are largely pristine. Initial haplotype data suggest that this foraging population consists of individuals from different rookeries throughout the Caribbean (Godley et al. 2004), but there are no data on the sex ratio.

\section{Sex ratios}

Primary sex ratios for hawksbill turtle rookeries exhibit, as in other marine turtle species, a female bias, although only 3 studies have been carried out in the Caribbean, where the majority of the global population of hawksbill turtles are found (Table 1). Since juvenile turtles do not display secondary sexual characteristics, internal examination of the gonads by laparoscope is a useful technique for sexing individuals (Owens 1997, Miller \& Limpus 2003, Wibbels 2003), but is a logistically demanding and invasive technique that is potentially dangerous to the turtle and therefore not widely employed (Wibbels 2003). Some studies have compared laparoscopic data with assays of testosterone and oestradiol-17 (from here on, ' $\mathrm{T}$ ' and ' $\mathrm{E} 2$ ', respectively) from blood samples of juvenile hawksbill turtles (Diez \& Van Dam 2003, Geis et al. 2003, Blanvillain et al. 2008). This demonstrated that plasma sex hormones can be used in isolation to estimate gonadal sex. Another 4 studies have reported the sex ratios of foraging aggregations of juvenile hawksbill turtles (Limpus 1992, Leon \& Diez 1999, Mortimer \& Crain 1999, Shima et al. 2004), and apart from one study (Diez \& Van Dam 2003), all reported a significant female bias, ranging from 2.4 to 4 females per male 
Table 1. Eretmochelys imbricata. Percentage of female hatchlings in previous studies

\begin{tabular}{|c|c|c|c|c|}
\hline Life stage & \% ᄋ & Location & Method & Source \\
\hline Hatchling & $\begin{array}{l}50.0 \\
75.0 \\
80.6 \\
90.0 \\
90.0\end{array}$ & $\begin{array}{l}\text { Antigua } \\
\text { Antigua } \\
\text { Guadeloupe } \\
\text { US Virgin Islands } \\
\text { Bahia, Brazil }\end{array}$ & $\begin{array}{l}\text { Temperature logger } \\
\text { Temperature logger } \\
\text { Temperature logger } \\
\text { Histological examination } \\
\text { Incubation duration }\end{array}$ & $\begin{array}{l}\text { Mrosovsky et al. (1992) } \\
\text { Glen \& Mrosovsky (2004) } \\
\text { Kamel \& Mrosovsky (2006) } \\
\text { Wibbels (1999) } \\
\text { Godfrey et al. (1999) }\end{array}$ \\
\hline Juvenile & $\begin{array}{l}44.5 \\
70.3 \\
72.0 \\
73.1 \\
73.3 \\
80.0 \\
67.3\end{array}$ & $\begin{array}{l}\text { Puerto Rico } \\
\text { Florida, USA } \\
\text { Great Barrier Reef, Australia } \\
\text { Dominican Republic } \\
\text { Chagos Archipelago } \\
\text { US Virgin Islands } \\
\text { Japan }\end{array}$ & $\begin{array}{l}\text { Blood hormone + laparoscopy } \\
\text { Blood hormone + laparoscopy } \\
\text { Laparoscopy + histology } \\
\text { Blood hormone } \\
\text { Blood hormone } \\
\text { Blood hormone + laparoscopy } \\
\text { Unknown }\end{array}$ & $\begin{array}{l}\text { Diez \& Van Dam (2003) } \\
\text { Blanvillain et al. (2008) } \\
\text { Limpus (1992) } \\
\text { Leon \& Diez (1999) } \\
\text { Mortimer \& Crain (1999) } \\
\text { Geis et al. (2003) } \\
\text { Shima et al. (2004) }\end{array}$ \\
\hline Adult & $62.9 / 94.3$ & Malaysia & Multiple paternity ${ }^{\mathrm{a}}$ & Joseph \& Shaw (2011) \\
\hline
\end{tabular}

(Limpus 1992, Leon \& Diez 1999, Geis et al. 2003, Blanvillain et al. 2008) (our Table 1). These studies represent only a fraction of the hawksbill turtle population in the Caribbean, and further information on the sex ratios of hawksbill foraging populations is needed.

\section{Climate change}

The study of sex ratios in marine turtles at all life history stages has recently been suggested as a priority to understand the ecological effects of anthropogenic climate change on marine turtles (Hamann et al. 2010). A problem could arise if future climate warming led to the production of a higher proportion of female hatchlings than at present or if the production of male hatchlings ceased from some beaches (Hawkes et al. 2007, Fuentes et al. 2009, Mitchell \& Janzen 2010, Valverde et al. 2010, Witt et al. 2010b). Understanding sex ratios is essential for the development of population models (Owens 1997, Hamann et al. 2010) for predicting effects of anthropogenic climate change (Hawkes et al. 2009).

\section{Aims and objectives}

In the present study, we set out to estimate the sex ratio of the juvenile hawksbill turtle foraging aggregation in the waters surrounding Anegada, BVI, one of the most important in the Caribbean (Fig. 1), using measures of plasma concentrations of the sex hormones $\mathrm{T}$ and $\mathrm{E} 2$. In addition, we critically review the utility of this approach in the Caribbean to predict sex, and explore the environmental and bio- logical variables that may be contributing to variation in hormone concentrations and predicted sex ratios.

\section{MATERIALS AND METHODS}

\section{Study site}

The island of Anegada $\left(18^{\circ} 30^{\prime} \mathrm{N}, 64^{\circ} 30^{\prime} \mathrm{W}\right)$ is the second largest island in the BVI archipelago and is the northern-most and eastern-most island of the Greater Antilles (Fig. 1). It is an emergent coral limestone platform rising to a maximum altitude of $8 \mathrm{~m}$ and is sparsely developed or inhabited, and is likely an important hawksbill turtle foraging site in the Caribbean (McGowan et al. 2008).

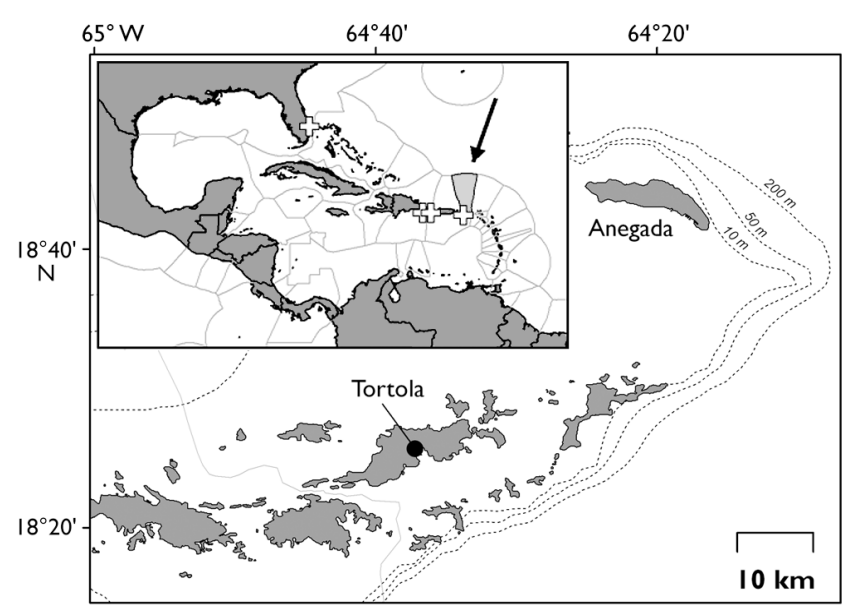

Fig. 1. Anegada, British Virgin Islands (BVI). Inset: location of the BVI; BVI EEZ in light grey (black arrow); white crosses: locations of 4 projects that recorded juvenile hawksbill turtle laparo-scopy sex ratios. Location sampled for photoperiod: Tortola 


\section{Turtle capture and sampling}

To sample foraging hawksbill turtles, we carried out an in-water capture programme between November 2003 and September 2005 (see also McGowan et al. 2008, Witt et al. 2010a). All sampling took place in shallow $(<15 \mathrm{~m})$ coastal waters, and turtles were captured by hand via a combination of free diving or the rodeo-style method (Ehrhart \& Ogren 1999). Each captured turtle was marked with unique numbered inconel flipper tags, and biometric data, including straight carapace length from notch to tip (SCL), was recorded (see also McGowan et al. 2008).

Immediately following capture, we collected 5 to $7 \mathrm{ml}$ of blood from the dorsocervical sinus of each turtle following Owens \& Ruiz (1980) using a $0.8 \times$ $38 \mathrm{~mm}$ needle and a vacutainer (Becton Dickinson). Blood samples were placed immediately on ice and stored for a maximum of $5 \mathrm{~h}$. Samples were then centrifuged for $10 \mathrm{~min}$ at $13000 \mathrm{rpm}$, and plasma was pipetted into cryogenic vials and stored at $-20^{\circ} \mathrm{C}$. Samples were then later shipped frozen to the University of Exeter, where they were stored at $-80^{\circ} \mathrm{C}$.

\section{Hormone analyses}

Concentrations of E2 and T were analysed using enzyme immune-assays (Cayman Chemical Company: 582701 Testosterone EIA kit and 582251 Estradiol EIA kit). Briefly, $2 \mathrm{ml}$ of plasma were extracted using $20 \mathrm{ml}$ diethyl ether. The ether was collected in a fresh vial and evaporated under a stream of nitrogen. Dried samples were re-suspended in assay buffer and analysed in duplicate. A standard curve was run on each 96-well plate, and hormone concentrations were calculated (pg ml-1) using the curve. Previously published values of hawksbill E2 and $\mathrm{T}$ concentrations of known-sex individuals from populations within a reasonable distance of our study site (Puerto Rico: Diez \& Van Dam 2003; US Virgin Islands: Geis et al. 2003; South Florida: Blanvillain et al. 2008; white crosses in Fig. 1) were used to assign sex.

\section{Environmental data}

We extracted data describing the sea surface temperature (SST) of the study site, using a fixed point just off the south coast of Anegada, from the MODIS Aqua satellite $8 \mathrm{~d}$ data (http://modis.gsfc.nasa.gov/). Where data were not available for an $8 \mathrm{~d}$ period (e.g. due to cloud cover), they were linearly interpolated. Photoperiod was calculated by deducting sunrise from sunset times for the island of Tortola, BVI (Fig. 1). We set day of year to start with 1 November = Day 1 (to a maximum of Day 365).

\section{Statistics}

All statistical analyses were conducted using GenStat, version 12.1 (VSN International). Data failed Shapiro-Wilk tests of normality and were therefore tested using non-parametric statistics (correlations were tested using the Spearman rank test, and differences between 2 variables using a Mann-Whitney $U$-test and between 3 variables using Kruskal-Wallis 1-way ANOVA). Sex ratios were tested for their deviation from 1:1 using Fisher's exact test. Statistical significance was assumed at $5 \%$.

\section{RESULTS}

\section{Turtles}

We sampled 62 juvenile hawksbill turtles (mean SCL: $33.8 \pm 0.83 \mathrm{~cm}$, range: 20.2 to $51.1 \mathrm{~cm}$ ). T concentration ranged from 12.7 to $1462.3 \mathrm{pg} \mathrm{ml}^{-1}$, with the majority $(65 \%)$ of turtles having $<100 \mathrm{pg} \mathrm{ml}^{-1} \mathrm{~T}$ (Fig. 2a), and were similar to $\mathrm{T}$ concentrations found in other studies (Fig. 2b). E2 concentrations ranged from 11.0 to $576.3 \mathrm{pg} \mathrm{ml}^{-1}$, and most individuals (89\%) had E2 concentrations $<100 \mathrm{pg} \mathrm{m}^{-1}$ (Fig. 2c). There were no studies with which to compare our E2 values. There were no significant differences between sampling years in either $\mathrm{T}$ (Mann-Whitney $U$-test: $\left.\mathrm{n}_{1}=33, \mathrm{n}_{2}=29, U=458, \mathrm{p}=0.78\right)$ or $\mathrm{E} 2$ concentrations (Mann-Whitney $U$-test: $\mathrm{n}_{1}=33, \mathrm{n}_{2}=29$, $U=390, \mathrm{p}=0.22$ ), and therefore data were combined for all further analyses.

\section{Sex ratios}

Hormone concentrations were compared with values from Geis et al. (2003), Diez \& Van Dam (2003) and Blanvillain et al. (2008) (the original published values in Diez \& Van Dam 2003 were an order of magnitude too low, but were corrected following Braun-McNeill et al. 2007). Where values for any of our turtles were outside published ranges (i.e. between the upper female limit and lower male limit), they were excluded from analysis. 

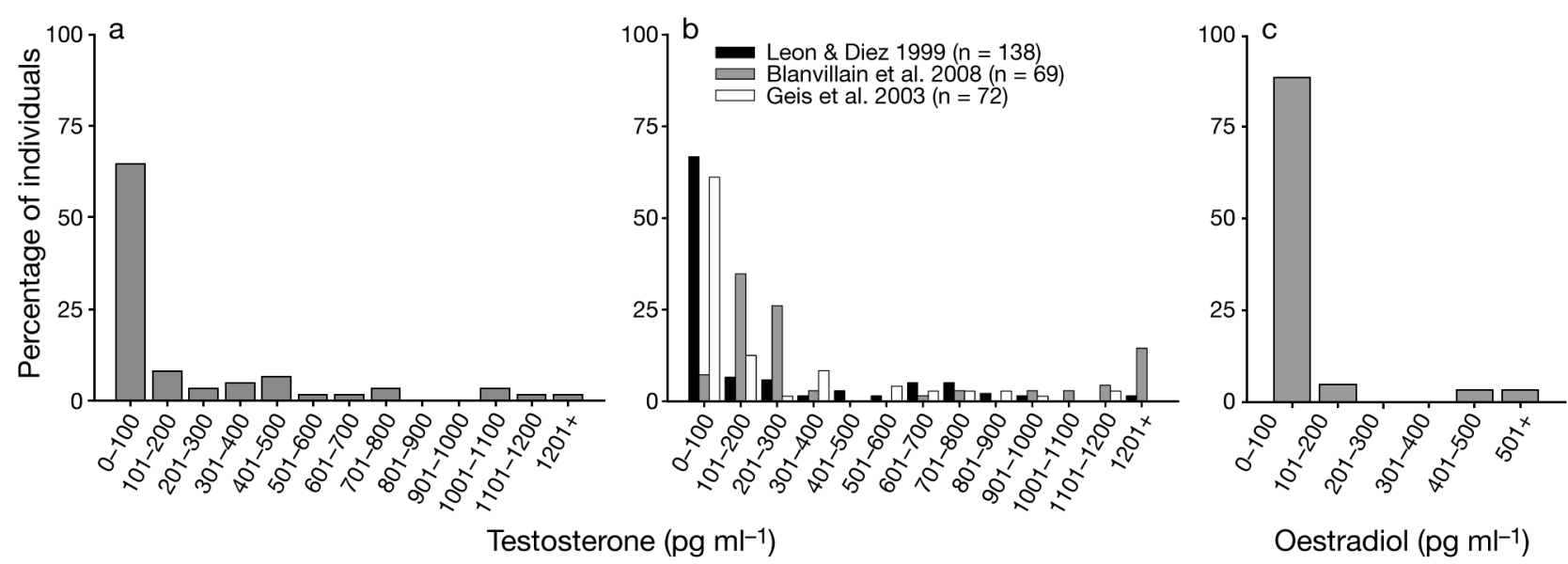

Fig. 2. Eretmochelys imbricata. Testosterone concentrations from (a) the present study (Anegada) and (b) other studies (Dominican Republic: Leon \& Diez 1999, US Virgin Islands: Geis et al. 2003, Florida: Blanvillain et al. 2008). (c) Oestradiol concentrations in the present study. Diez \& Van Dam (2003) is excluded from (b) because no individual testosterone concentrations were presented

Table 2. Eretmochelys imbricata. Estimated sex ratios of the foraging population in the waters surrounding Anegada between November 2003 and September 2005, utilising critical thresholds of plasma testosterone (T) for the assignment of sex

\begin{tabular}{|c|c|c|c|c|c|c|c|c|}
\hline \multicolumn{2}{|c|}{ Testosterone $\left(\mathrm{pg} \mathrm{ml}^{-1}\right)$} & \multirow[t]{2}{*}{ Female } & \multirow[t]{2}{*}{ Male } & \multirow[t]{2}{*}{ Unknown } & \multicolumn{3}{|c|}{ Female:male ratio } & \multirow[t]{2}{*}{ Source } \\
\hline Female & Male & & & & Mean & Min & Max & \\
\hline$\leq 162^{\mathrm{a}}$ & $\geq 200^{\mathrm{a}}$ & 42 & 17 & 3 & $2.5: 1$ & 2.1:1 & $2.6: 1$ & Leon \& Diez (1999) \\
\hline$\leq 170^{\mathrm{a}}$ & $\geq 182^{\mathrm{a}}$ & 42 & 19 & 1 & $2.2: 1$ & $2.1: 1$ & $2.3: 1$ & Diez \& Van Dam (2003) \\
\hline$\leq 185.6$ & $\geq 459.9$ & 44 & 9 & 9 & $4.9: 1$ & $2.4: 1$ & $5.0: 1$ & Geis et al. (2003) \\
\hline$\leq 260.8$ & $\geq 720.5$ & 46 & 6 & 10 & $7.7: 1$ & $2.9: 1$ & $9.3: 1$ & Blanvillain et al. (2008) \\
\hline
\end{tabular}

Based on these ranges, in our study, there were between 2.4 and 7.7 females per male (46 females to 6 males and 43 females to 18 males; thresholds from Diez \& Van Dam 2003 and Blanvillain et al. 2008, respectively, using 61 and 52 turtles from the present study that fell within their limits, respectively; our Table 2). Even if we were to assume the least female-biased estimates possible (assuming all unknown sex individuals to be male), there were at least 2.1 females per male (thresholds from Diez \& Van Dam 2003), which is significantly different from a 1:1 sex ratio (Fisher's exact test: $p=$ 0.048 .

In the present study, $\mathrm{T}$ and $\mathrm{E} 2$ concentrations were correlated (Spearman rank correlation: $\mathrm{r}_{\mathrm{S}}=0.29, \mathrm{df}=$ $60, t=2.4, \mathrm{p}=0.02$; Fig. 3). Values for both hormones, however, span more than an order of magnitude, and the significance of the relationship is affected by removal of 3 turtles that had unusually high concentrations of both hormones (Spearman rank correlation: $\mathrm{r}_{\mathrm{S}}=0.22, \mathrm{df}=57, t=1.71, \mathrm{p}=0.09$; Fig. 3 ) and thus may have been intersex individuals as described by Limpus (1992).

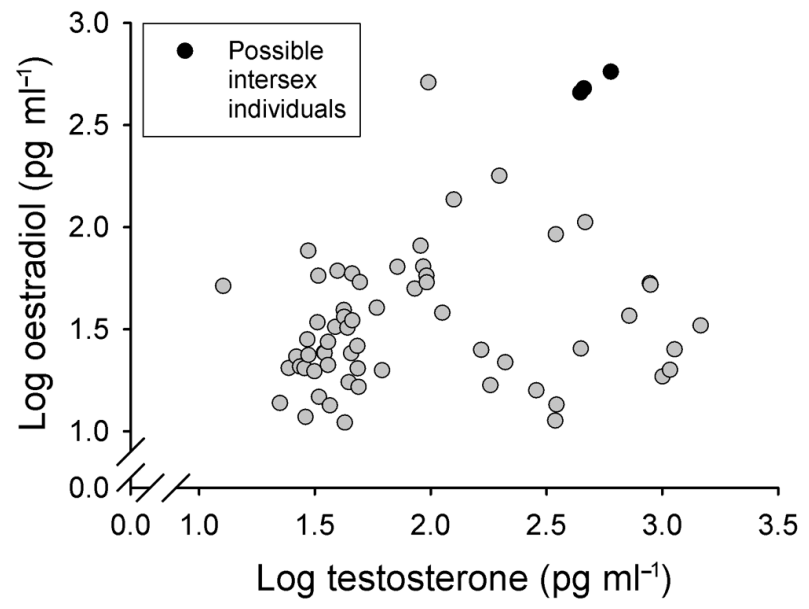

Fig. 3. Eretmochelys imbricata. Significant log relationship between testosterone and oestradiol concentrations in 62 juveniles sampled in Anegada (Spearman's $\mathrm{r}_{\mathrm{S}}=0.29$, $\mathrm{df}=60$, $t=2.4, \mathrm{p}<0.05)$

There was no significant difference in the size of turtles sampled across seasons (Kruskal-Wallis 1-way ANOVA: $H=6.7, \mathrm{df}=3, \mathrm{p}=0.08$ ). There was also no significant difference in either $\mathrm{T}(H=1.4, \mathrm{df}=3, \mathrm{p}=$ 

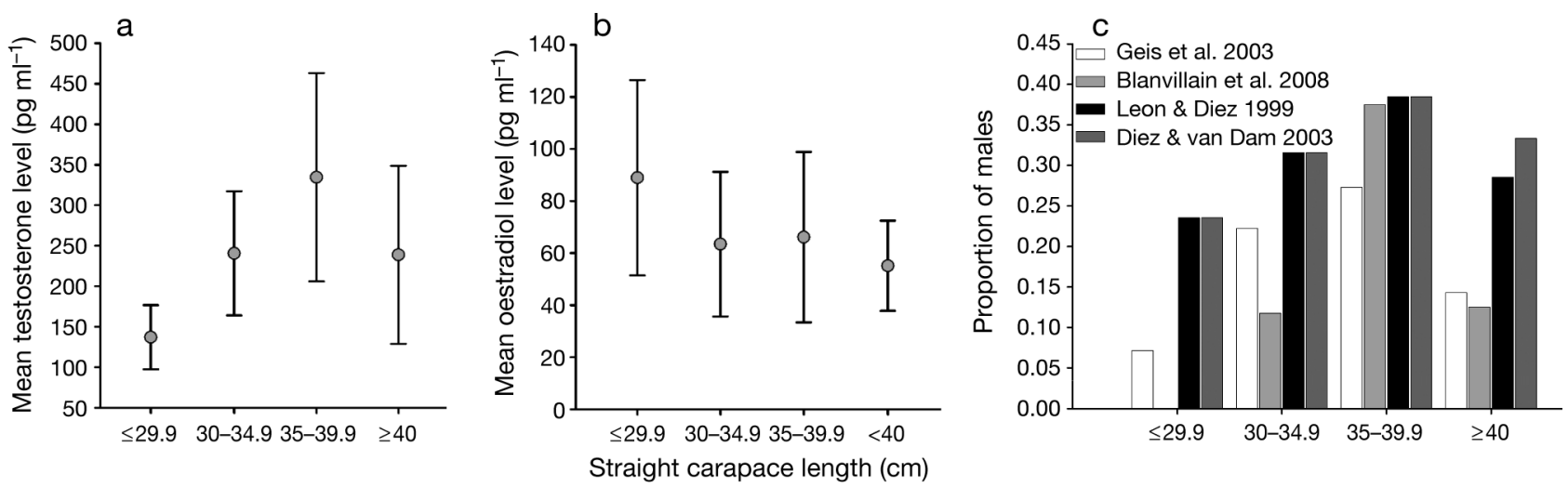

Fig. 4. Eretmochelys imbricata. Blood concentrations (mean \pm SD) of (a) testosterone and (b) oestradiol in relation to carapace lengths of 59 juveniles ( 3 turtles were not measured). (c) Proportion of male turtles from the present study in each size class as determined using threshold hormone values from previous studies (Table 2)

$0.71)$ or $\mathrm{E} 2(H=0.6, \mathrm{df}=3, \mathrm{p}=0.90)$ concentrations by turtle size (Fig. $4 \mathrm{a}, \mathrm{b}$ ). The distribution of turtle sizes in the present study compared to other studies of juvenile hawksbill turtles is shown in Fig. 4c and the number of unsexed individuals is in Table 3.

\section{Environmental conditions}

There was a significant positive correlation between date and $\mathrm{T}$ concentration (Spearman rank correlation: $\mathrm{r}_{\mathrm{S}}=0.37, \mathrm{df}=60, t=3.1, \mathrm{p}=0.003$; Fig. 5a) but not between date and $\mathrm{E} 2$ concentration $\left(\mathrm{r}_{\mathrm{S}}=0.11\right.$, $\mathrm{df}=60, t=0.9, \mathrm{p}=0.38$ ). It was also apparent that as

Table 3. Eretmochelys imbricata. Number of turtles in each of 4 size classes and number that could not be sexed because their testosterone concentrations fell between the sexspecific threshold limits, in 4 studies across the Caribbean

\begin{tabular}{|lccl|}
\hline $\begin{array}{l}\text { Size } \\
(\mathrm{cm})\end{array}$ & $\begin{array}{c}\text { Sample } \\
(\mathrm{n})\end{array}$ & $\begin{array}{c}\text { Not sexed } \\
(\mathrm{n})\end{array}$ & \multicolumn{1}{c|}{ Source } \\
\hline$<29.9$ & 14 & 3 & Geis et al. (2003) \\
& 0 & 0 & Blanvillain et al. (2008) \\
& 17 & 0 & Leon \& Diez (1999) \\
& 17 & 0 & Diez \& Van Dam (2003) \\
$30-34.9$ & 18 & 2 & Geis et al. (2003) \\
& 17 & 3 & Blanvillain et al. (2008) \\
& 19 & 1 & Leon \& Diez (1999) \\
& 19 & 1 & Diez \& Van Dam (2003) \\
$35-39.9$ & 11 & 2 & Geis et al. (2003) \\
& 11 & 2 & Blanvillain et al. (2008) \\
& 13 & 0 & Leon \& Diez (1999) \\
& 13 & 0 & Diez \& Van Dam (2003) \\
$>40$ & 7 & 2 & Geis et al. (2003) \\
& 8 & 1 & Blanvillain et al. (2008) \\
& 7 & 2 & Leon \& Diez (1999) \\
& 9 & 0 & Diez \& Van Dam (2003) \\
& & &
\end{tabular}

SSTs became higher, the variance in T levels increased (Fig. 6a). Given the seasonal effect on $\mathrm{T}$ concentrations, we looked for potential correlations between the environmental measures of SST and photoperiod, which have a strong seasonal component (Fig. 5b,c), and blood serum hormone concentrations. Concentrations of $\mathrm{T}$ peaked shortly before SSTs reached their maxima, beginning to drop as photoperiod began to shorten (Fig. 5a).

There was a significant positive correlation between $\mathrm{T}$ concentrations and SST, with higher $\mathrm{T}$ concentrations in turtles found at higher temperatures (Spearman rank correlation: $\mathrm{r}_{\mathrm{S}}=0.26, \mathrm{df}=60, t=2.1, \mathrm{p}=0.04$; Fig. 6a). There was no relationship between SST and E2 concentrations (Fig. 6b). Neither T nor E2 concentrations were significantly related to photoperiod (Spearman rank correlation: $p>0.05$ ), although SST and photoperiod were correlated $\mathrm{r}_{\mathrm{S}}=0.54, \mathrm{df}=60, t=$ 5.0, $\mathrm{p}<0.001)$.

\section{DISCUSSION}

\section{Sex ratios}

Our results suggest that 69 to $89 \%$ of juvenile hawksbill turtles foraging around Anegada may have been female. It was not possible to estimate whether sampling bias may have affected the estimated sex ratios in this study, but these results should not have been influenced by the presence of any adult female nesting turtles, as we only captured juveniles. Our values are in broad agreement with other studies (Kichler et al. 1999, Jensen et al. 2006, Theissinger et al. 2009, Hays et al. 2010, Joseph \& Shaw 2011), including those for Caribbean hawksbill turtles (Leon \& Diez 1999, Geis et al. 2003), and with 

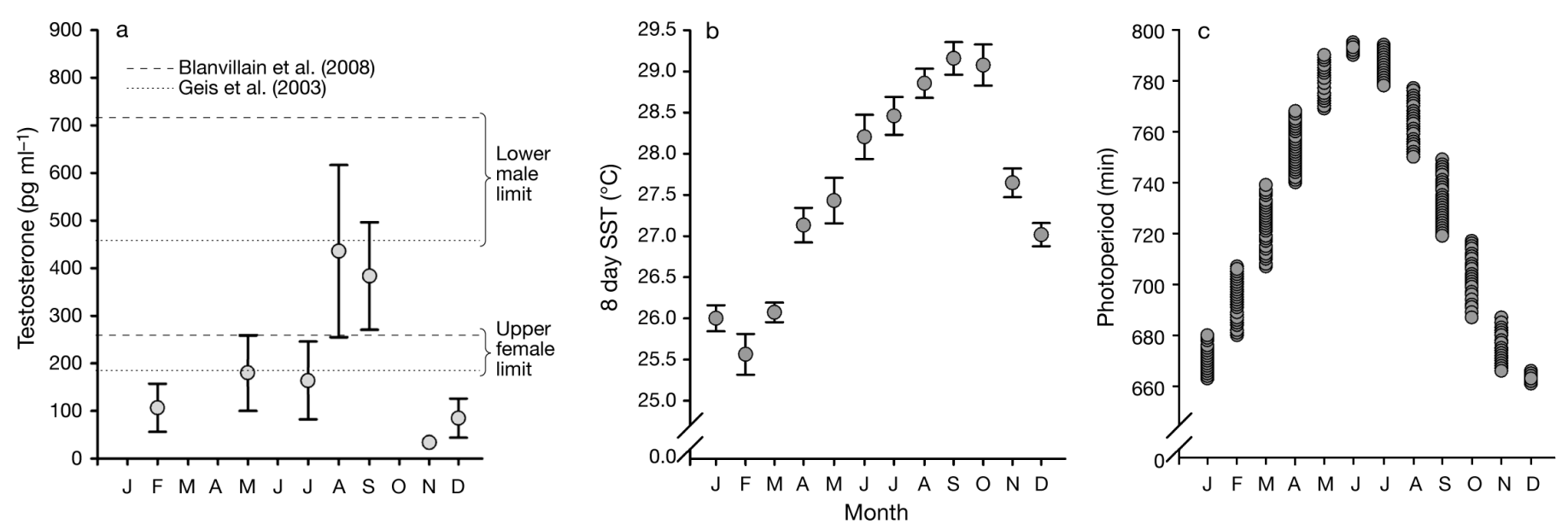

Fig. 5. Eretmochelys imbricata. Variation and pattern in monthly (a) mean testosterone concentrations of 62 juveniles, (b) mean sea surface temperature (SST), (c) photoperiod, at Anegada between November 2003 and September 2005. Error bars: SD. Horizontal dashed lines in (a) show the upper female and lower male limit in Blanvillain et al. (2008) and Geis et al. (2003) respectively (line types indicated on plot), in which females were identified below 260.8 and 185.6 pg ml $^{-1}$ respectively and males were identified above 720.5 and $459.5 \mathrm{pg} \mathrm{ml}^{-1}$ respectively

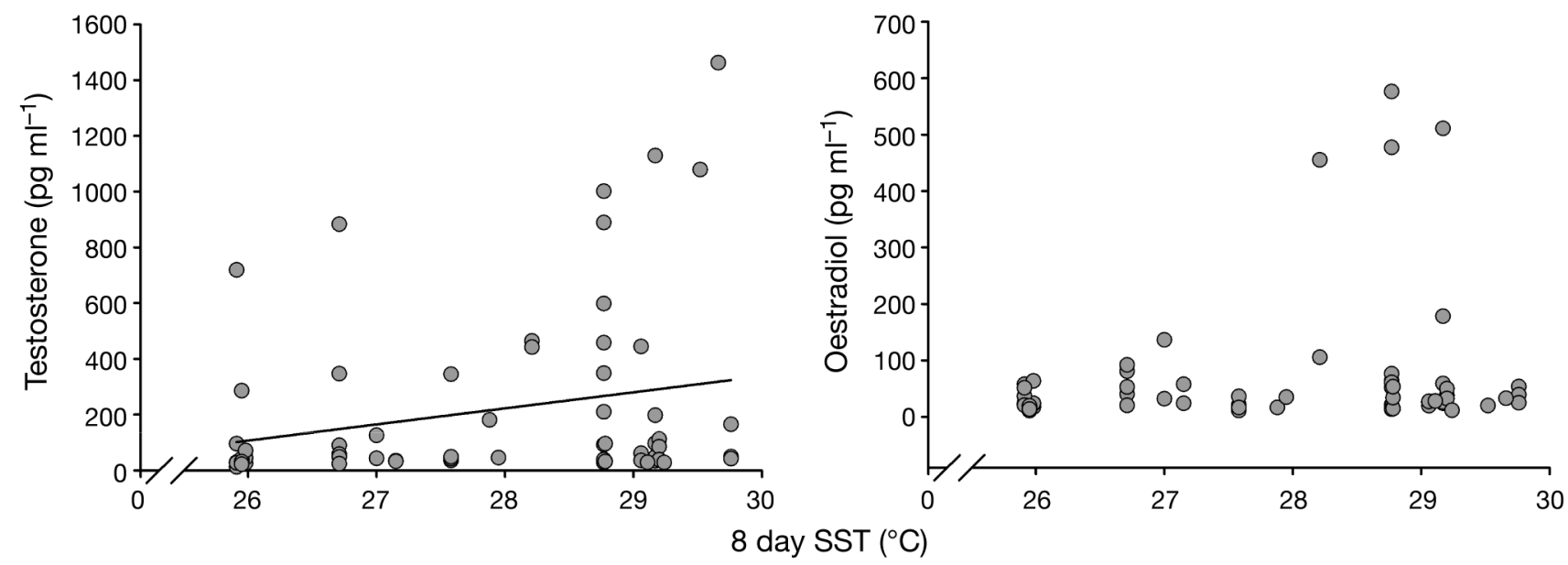

Fig. 6. Eretmochelys imbricata. Significant relationship between sea surface temperature and (a) testosterone and (b) oestradiol in 62 juveniles sampled in Anegada (Spearman's $\mathrm{r}_{\mathrm{S}}=0.26, \mathrm{df}=60, t=2.1, \mathrm{p}<0.05$ ). Linear regression line for (a) is shown

primary sex ratios of hawksbill turtles reported from Antigua (Mrosovsky et al. 1992, Glen \& Mrosovsky 2004), the West Indies (Kamel \& Mrosovsky 2006) and the US Virgin Islands (Wibbels 1999) (our Table 1).

The secondary sex ratio can be less female-biased than the primary sex ratio (Kichler et al. 1999, Jensen et al. 2006, Theissinger et al. 2009, Hays et al. 2010, Joseph \& Shaw 2011, Stewart \& Dutton 2011, Wright et al. 2012a, 2012b), suggesting differential recruitment by the sexes to juvenile foraging aggregations. This could be for 2 reasons: either (1) some female hatchlings recruit elsewhere (sex-biased dispersal; Casale et al. 2002); and/or (2) female hatchlings suffer greater mortality than male hatchlings. The second hypothesis is supported by findings that hatchlings from cooler nests (and thus likely male- producing nests) had enhanced locomotor performance compared with hatchlings from warmer nests (Booth \& Evans 2011), as well as larger body size (Booth \& Astill 2001), and such increased swimming performance and size could reduce their relative exposure to predation (Janzen et al. 2000).

\section{Methodology}

Our results show for the first time in the Caribbean that there is a strong seasonal component to $\mathrm{T}$ concentrations, and suggest that the timing of sampling of individuals could affect estimated sex ratio. This has also been shown in juvenile loggerhead turtles in USA waters, where $\mathrm{T}$ concentrations were reliable 
indicators of sex only during the summer months, when water temperatures were $>23^{\circ} \mathrm{C}$ (Braun-McNeill et al. 2007), but the opposite was true for adult loggerhead turtles (Wibbels et al. 1987, Owens 1997). Seasonal variation in $\mathrm{T}$ has also been shown for other reptiles (Gowan et al. 2010, Kakizoe et al. 2010, Hamlin et al. 2011, Boretto et al. 2012), and may maximise mating opportunities during the season when females are receptive. For juveniles this may serve no purpose until sexual maturity, but the drivers of the seasonal variation are currently not understood.

Future studies could describe how hormone profiles change throughout the year by repeatedly sampling known-sex individuals, which would greatly inform future methodologies for in-water sexing of marine turtles and help to develop robust marker systems. Furthermore, the reliability of $\mathrm{T}$ estimates could vary not only across species but within species occupying different water temperature profiles, and this could have implications for using published critical limits for assigning sex. These temperature profiles may, of course, alter with future climate change, leading to further complications in estimations of sex ratios from threshold hormone values. It seems clear that concentrations of both hormones may be highly variable, and further work is required to understand the drivers of this. In addition, nothing is yet known about the ontogeny of the absolute and seasonal expression of sex hormones in marine turtles, making it complex to compare between life stages. Regardless, the thermal environment experienced by hawksbill turtles in the Caribbean varies much less than the habitat experienced by loggerhead turtles on the seasonally dynamic USA coast (Braun-McNeill et al. 2007, Hawkes et al. 2011), so one might expect that the window of reliability of $\mathrm{T}$ estimates of sex may be wider.

Measures of circulating E2 were not very informative in the present study for juvenile turtles in isolation, but in conjunction with $\mathrm{T}$, they may have helped to identify intersex individuals. Two turtles in Limpus (1992) with high concentrations of both hormones were examined by laparoscope and could not be identified as male or female (one having features of gonads from both sexes and the other neither). High concentrations of E2 could result from warm temperatures stimulating activity of the enzyme aromatase, which converts T into E2 (Hau 2007). Thus, male turtles could appear as intersex individuals as a result of temperature-mediated aromatase action. The extent to which sex hormones are useful in assigning sex is not known for other life stages of marine turtles, but $\mathrm{T}$ and $\mathrm{E} 2$ are known to vary dramatically over the course of a year for all life stages and species (Owens 1997). In the present study, $5 \%(3 / 62)$ of sampled individuals could have been intersex, as they exhibited high concentrations of both E2 and T. The 3 turtles were not particularly large (and therefore probably not more mature than others in the present study; $38.5,25.5$ and $35.5 \mathrm{~cm}$ SCL respectively), but were all captured between 2 August and 25 September, when our data show that sex hormone concentrations were generally higher. These hormones may also have additional roles in juvenile turtles, such as bone growth and development and immune function, that are not yet understood. Our assessment is, however, speculative because we did not conduct laparoscopy, and our results highlight the importance of using multiple criteria, where possible, to estimate sex ratio. Finally, it seems clear that a robust threshold value of $\mathrm{T}$ for sexing turtles, regardless of the species, ocean basin or time of year, may not be found.

\section{Foraging stock composition}

An important next step would be to gain an understanding of the provenance of these juvenile foraging aggregations. Genetic work and satellite tracking over the last 15 yr has demonstrated that hawksbill turtles sharing a Caribbean foraging site usually come from distant as well as local rookeries (Bass 1999, Diaz-Fernandez et al. 1999, Horrocks et al. 2001, 2011, Troëng et al. 2005, Bowen et al. 2007, Mortimer et al. 2007, Van Dam et al. 2008, Blumenthal et al. 2009, Browne et al. 2010, Meylan et al. 2011, Moncada et al. 2012). Initial haplotype data for Anegada suggests that the BVI foraging population consists of individuals from several different source rookeries throughout the Caribbean basin (Godley et al. 2004), but enumerating the likely proportion of each would be an important demographic parameter for predictive models of climate change effects. For example, such data could permit insights into potential sexbiased dispersal or mortality during the 'lost years' for which no data currently exist (see Witherington et al. 2012).

From a conservation perspective, information on the sex ratio and source of local foraging aggregations is paramount, as individual nation-state management strategies (including consumptive use of marine turtles) could have implications beyond national boundaries (see Moncada et al. 2012 for more detailed discussion). Primary sex ratios and molecular profiles for many Caribbean rookeries remain to be described and should be collected as a 
conservation priority. Indeed, a more accurate picture of likely population changes under future climate scenarios could be gained with such parameters (e.g. the primary sex ratio of each source population, more information about the conversion of primary sex ratios into secondary sex ratios in foraging aggregations and relative contributions to different foraging aggregations) (Blumenthal et al. 2009).

\section{Adaptation to climate change}

These data suggest that the secondary sex ratios of Caribbean hawksbill sea turtles in the BVI may not be highly female-skewed, and importantly, that primary sex ratio is not necessarily a good indicator of secondary sex ratio. The existence of sufficient male turtles in the population is obviously important to maintain reproduction, but the presence of at least $25 \%$ males has been suggested as an important conservation target in monitoring the future effects of climate change (Poloczanska et al. 2009). The potentially relatively high proportion of juvenile male turtles in the present study population suggests a level of resilience against the future effects of climate change. Recent research (Joseph \& Shaw 2011, Stewart \& Dutton 2011, Wright et al. 2012b) has suggested that the operational sex ratios of adult populations of marine turtles could be even less female-biased still.

Why a female bias exists in most marine turtle populations is poorly understood and it remains unclear whether it is advantageous in an ecological or evolutionary sense. How might warmer conditions provide for higher fitness for female marine turtles? Recent work with lizards demonstrated enhanced growth of males and females at different incubation temperatures, confirming for the first time the predictions in the Charnov-Bull model for a reptile species (Warner \& Shine 2008). Experimental work has yet to be carried out to demonstrate if this is likely to be the case for marine turtles, although with long periods to maturity and slow growth rates, this is a challenge. In addition, early modelling work has suggested that, through climate change, the proportion of female turtles at large in the population should increase still further (Hawkes et al. 2007, Fuentes et al. 2009, Mitchell \& Janzen 2010, Valverde et al. 2010), and thus the pace of change may proceed more quickly than our understanding of the system before perturbation. We advocate that all marine turtle research programmes working with foraging aggregations of marine turtles routinely collect blood and tissue samples to enable secondary sex ratio estimates and assignment of source rookeries. Only then can models be built that will permit prediction of the effect of climate change.

\section{CONCLUSIONS}

We report secondary sex ratios for juvenile hawksbill turtles around Anegada, BVI, that are less femalebiased than many reported primary (hatchling) sex ratios for the region, but concentrations of plasma $\mathrm{T}$ are variable and should be interpreted with caution. In particular, there may be seasonal endogenous or environmental exogenous cues that drive fluctuations in hormone concentrations, and understanding the drivers for this will be key to estimating sex ratios in the future.

Acknowledgements. This work was partly funded by the UK Darwin Initiative (Project Ref. No. 162/12/023), Natural Environment Research Council (NERC) and the Japan Bekko Association. L.A.H. is supported by a BBSRC postdoctoral grant, and M.J.W. was in receipt of a NERC PhD studentship (NER/S/A/2004/12980). A.L. was funded by a NERC grant (NE/E016634/1) to C.R.T. We thank the BVI National Parks Trust for their support and assistance, and Jan Shears (University of Exeter) for help with the plasma extractions. All work was sanctioned by the Conservation and Fisheries Department of the British Virgin Islands Government. We thank 3 anonymous reviewers for comments that improved the manuscript.

\section{LITERATURE CITED}

Bass AL (1999) Genetic analysis to elucidate the natural history and behaviour of hawksbill turtles (Eretmochelys imbricata) in the wider Caribbean: a review and reanalysis. Chelonian Conserv Biol 3:195-199

Blanvillain G, Wood LD, Meylan AB, Meylan PA (2008) Sex ratio prediction of juvenile hawksbill sea turtles (Eretmochelys imbricata) from South Florida, USA. Herpetol Conserv Biol 3:21-27

> Blumenthal JM, Abreu-Grobois FA, Austin TJ, Broderick AC and others (2009) Turtle groups or turtle soup: dispersal patterns of hawksbill turtles in the Caribbean. Mol Ecol 18:4841-4853

Booth DT, Astill K (2001) Incubation temperature, energy expenditure and hatchling size in the green turtle (Chelonia mydas), a species with temperature-sensitive sex determination. Aust J Zool 49:389-396

Booth DT, Evans A (2011) Warm water and cool nests are best. How global warming might influence hatchling green turtle swimming performance. PLoS ONE e23162

Boretto JM, Jahn GA, Fornes MW, Cussac VE, Ibarguengoytia NG (2012) How males synchronise their reproductive cycles with females to cope with seasonal climate: an endocrinal and ultrastructural study of Phymatus zapalensis lizards (Liolaemidae). Herpetol J 22:33-42

Bowen BW, Grant WS, Hillis-Starr Z, Shaver DJ, Bjorndal KA, Bolten AB, Bass AL (2007) Mixed-stock analysis 
reveals the migrations of juvenile hawksbill turtles (Eretmochelys imbricata) in the Caribbean Sea. Mol Ecol 16:49-60

Braun-McNeill J, Epperly SP, Owens DW, Avens L, Williams E, Harms CA (2007) Seasonal reliability of testosterone radioimmunoassay (RIA) for predicting sex ratios of juvenile loggerhead (Caretta caretta) turtles. Herpetologica 63:275-284

Browne D, Horrocks J, Abreu-Grobois F (2010) Population subdivision in hawksbill turtles nesting on Barbados, West Indies, determined from mitochondrial DNA control region sequences. Conserv Genet 11:1541-1546

> Casale P, Laurent L, Gerosa G, Argano R (2002) Molecular evidence of male-biased dispersal in loggerhead turtle juveniles. J Exp Mar Biol Ecol 267:139-145

Charnov EL, Bull J (1977) When is sex environmentally determined? Nature 266:828-830

Diaz-Fernandez R, Okayama T, Uchiyama T, Carillo E and others (1999) Genetic sourcing for the hawksbill turtle Eretmochelys imbricata in the northern Caribbean region. Chelonian Conserv Biol 3:296-300

> Diez CE, Van Dam RP (2003) Sex ratio of an immature hawksbill seaturtle aggregation at Mona Island, Puerto Rico. J Herpetol 37:533-537

Ehrhart LM, Ogren LH (1999) Studies in foraging habitats: capturing and handling turtles. In: Eckert KL, Bjorndal KA, Abreu-Grobois FA, Donnelly M (eds) Research and management techniques for the conservation of sea turtles. Publ No. 4. IUCN/SSC Marine Turtle Specialist Group, Washington, DC, p 61-64

Fisher RA (1930) The genetical theory of natural selection. Oxford University Press, Oxford

Fletemeyer J (1984) National report for the British Virgin Islands to the Western Atlantic Symposium. In: Bacon P, Perry F, Bjorndal K, Hirth H, Ogren I, Weber M (eds) Proc Western Atlantic Turtle Symp, Vol. 3. University of Miami Press, Miami, FL, p. 70-117

> Fuentes MMPB, Maynard JA, Guinea M, Bell IP, Werdell PJ, Hamann M (2009) Proxy indicators of sand temperature help project impacts of global warming on sea turtles in northern Australia. Endang Species Res 9:33-40

> Geis A, Wibbels T, Phillips B, Hillis-Starr Z and others (2003) Predicted sex ratio of juvenile hawksbill seaturtles inhabiting Buck Island Reef National Monument, U.S. Virgin Islands. J Herpetol 37:400-404

> Glen F, Mrosovsky N (2004) Antigua revisited: the impact of climate change on sand and nest temperatures at a hawksbill turtle (Eretmochelys imbricata) nesting beach. Glob Change Biol 10:2036-2045

Godfrey MH, D'Amato AF, Marcovaldi MÃ, Mrosovsky N (1999) Pivotal temperature and predicted sex ratios for hatchling hawksbill turtles from Brazil. Can J Zool 77: 1465-1473

Godley BJ, Broderick AC, Campbell LM, Ranger S, Richardson PB (2004) An assessment of the status and exploitation of marine turtles in the British Virgin Islands. In: Godley BJ, Broderick AC, Campbell LM, Ranger S, Richardson PB (eds) An assessment of the status and exploitation of marine turtles in the UK overseas territories in the wider Caribbean. Final project report for the Department of Environment, Food and Rural Affairs and the Foreign and Commonwealth Office, p 78-95

Godley BJ, Blumenthal JM, Broderick AC, Coyne MS, Godfrey MH, Hawkes LA, Witt MJ (2008) Satellite tracking of sea turtles: where have we been and where do we go next? Endang Species Res 4:3-22

Gowan TA, McBrayer LD, Rostal DC (2010) Seasonal variation in testosterone and performance in males of a nonterritorial lizard species. Physiol Behav 100:357-363

> Hamann M, Godfrey MH, Seminoff JA, Arthur K and others (2010) Global research priorities for sea turtles: informing management and conservation in the 21 st century. Endang Species Res 11:245-269

Hamlin HJ, Lowers RH, Guillette LJ Jr (2011) Seasonal androgen cycles in adult male American alligators (Alligator mississippiensis) from a barrier island population. Biol Reprod 85:1108-1113

Hastings M (1992) Survey of hawksbill / green turtle nesting sites in 1990 and 1991 in the British Virgin Islands. In: M.o.N.R.a.L. (ed) Tech Rep No. 13. Conservation and Fisheries Department, British Virgin Islands

> Hau M (2007) Regulation of male traits by testosterone: implications for the evolution of vertebrate life histories. Bioessays 29:133-144

> Hawkes LA, Broderick AC, Godfrey MH, Godley BJ (2007) Investigating the potential impacts of climate change on a marine turtle population. Glob Change Biol 13:923-932

> Hawkes LA, Broderick AC, Godfrey MH, Godley BJ (2009) Climate change and marine turtles. Endang Species Res $7: 137-154$

Hawkes LA, Witt MJ, Broderick AC, Coker JW and others (2011) Home on the range: spatial ecology of loggerhead turtles in Atlantic waters of the USA. Divers Distrib 17: 624-640

> Hays GC, Fossette S, Katselidis KA, Schofield G, Gravenor MB (2010) Breeding periodicity for male sea turtles, operational sex ratios, and implications in the face of climate change. Conserv Biol 24:1636-1643

Horrocks JA, Vermeer LA, Krueger B, Coyne M, Schroeder BA, Balazs GH (2001) Migration routes and destination characteristics of post-nesting hawksbill turtles satellitetracked from Barbados, West Indies. Chelonian Conserv Biol 4:107-114

Horrocks JA, Krueger BH, Fastigi M, Pemberton EL, Eckert KL (2011) International movements of adult female hawksbill turtles (Eretmochelys imbricata): first results from the Caribbean's Marine Turtle Tagging Centre. Chelonian Conserv Biol 10:18-25

Janzen FJ, Phillips PC (2006) Exploring the evolution of environmental sex determination, especially in reptiles. J Evol Biol 19:1775-1784

Janzen FJ, Tucker JK, Paukstis GL (2000) Experimental analysis of an early life-history stage: selection on size of hatchling turtles. Ecology 81:2290-2304

Jensen MP, Abreu-Grobois FA, Frydenberg J, Loeschcke V (2006) Microsatellites provide insight into contrasting mating patterns in arribada vs. non-arribada olive ridley sea turtle rookeries. Mol Ecol 15:2567-2575

Joseph J, Shaw P (2011) Multiple paternity in egg clutches of hawksbill turtles (Eretmochelys imbricata). Conserv Genet 12:601-605

Kakizoe Y, Fujiwara M, Akune Y, Kanou Y, Saito T, Uchida I (2010) Cyclical changes of plasma sex steroids in captive breeding loggerhead turtles (Caretta caretta). J Zoo Wildl Med 41:643-648

> Kamel SJ, Mrosovsky N (2006) Deforestation: risk of sex ratio distortion in hawksbill sea turtles. Ecol Appl 16: 923-931

Kichler K, Holder MT, Davis SK, Marquez R, Owens DW (1999) Detection of multiple paternity in the Kemp's rid- 
ley sea turtle with limited sampling. Mol Ecol 8:819-830

Leon YM, Diez CE (1999) Population structure of hawksbill turtles on a foraging ground in the Dominican Republic. Chelonian Conserv Biol 3:230-236

Limpus CJ (1992) The hawksbill turtle, Eretmochelys imbricata, in Queensland: population structure within a southern Great Barrier Reef feeding ground. Wildl Res 19:489-505

McGowan A, Broderick AC, Frett G, Gore S and others (2008) Down but not out: marine turtles of the British Virgin Islands. Anim Conserv 11:92-103

Meylan PA, Meylan AB, Gray JA (2011) The ecology and migrations of sea turtles 8 . Tests of the developmental habitat hypothesis. Bull Am Mus Nat Hist 357:1-70

Miller JD, Limpus CJ (2003) Ontogeny of marine turtle gonads. In: Lutz PL, Musick JA, Wyneken J (eds) Biology of sea turtles, Book 2. CRC Press, Boca Raton, FL, p 119-224

Mitchell NJ, Janzen FJ (2010) Temperature-dependent sex determination and contemporary climate change. Sex Dev 4:129-140

Moncada FG, Hawkes LA, Fish MR, Godley BJ and others (2012) Patterns of dispersal of hawksbill turtles from the Cuban shelf inform scale of conservation and management. Biol Conserv 148:191-199

Mortimer JA, Crain DA (1999) Chapter 13: Sex steroid concentrations in immature hawksbill turtles (Eretmochelys imbricata) in the Chagos archipelago. In: Sheppard CRC, Seaward MRD (eds) Ecology of the Chagos Archipelago, Book 2. Linnaean Society Occasional Publications, p 173-184

Mortimer JA, Meylan PA, Donnelly M (2007) Whose turtles are they, anyway? Mol Ecol 16:17-18

- Mrosovsky N (1988) Pivotal temperatures for loggerhead turtles (Caretta caretta) from northern and southern nesting beaches. Can J Zool 66:661-669

Mrosovsky N, Bass A, Corliss LA, Richardson JI, Richardson TH (1992) Pivotal and beach temperatures for hawksbill turtles nesting in Antigua. Can J Zool 70:1920-1925

Owens DW (1997) Hormones in the life history of sea turtles. In: Lutz PL, Musick JA (eds) The biology of sea turtles. CRC Press, Boca Raton, FL, p 315-341

Owens DW, Ruiz GJ (1980) New methods of obtaining blood and cerebrospinal fluid from marine turtles. Herpetologica 36:17-20

> Poloczanska ES, Limpus CJ, Hays GC (2009) Vulnerability of marine turtles to climate change. Adv Mar Biol 56: 151-211

Richardson PB, Broderick AC, Campbell LM, Godley BJ, Ranger S (2006) Marine turtle fisheries in the UK overseas territories of the Caribbean: domestic legislation and the requirements of multilateral agreements. J Int Wildl Law Policy 9:223-246

Shima T, Kamezaki N, Kuroyanagi K (2004) The population structure and sex ratio of hawksbill sea turtles (Eretmochelys imbricata) inhabiting the Yaeyama Islands. Zool Sci 21:1348

Smith JM, Price GR (1973) The logic of animal conflict. Nature 246:15-18

Stewart KR, Dutton PH (2011) Paternal genotype reconstruction reveals multiple paternity and sex ratios in a breeding population of leatherback turtles (Dermochelys coriacea). Conserv Genet 12:1101-1113

Theissinger K, FitzSimmons N, Limpus C, Parmenter C,
Phillott A (2009) Mating system, multiple paternity and effective population size in the endemic flatback turtle (Natator depressus) in Australia. Conserv Genet 10: 329-346

> Troëng S, Dutton PH, Evans D (2005) Migration of hawksbill turtles Eretmochelys imbricata from Tortuguero, Costa Rica. Ecography 28:394-402

> Valverde RA, Wingard S, Gomez F, Tordoir MT, Orrego CM (2010) Field lethal incubation temperature of olive ridley sea turtle Lepidochelys olivacea embryos at a mass nesting rookery. Endang Species Res 12:77-86

- Van Dam RP, Diez CE, Balazs GH, Colon LAC, McMillan WO, Schroeder B (2008) Sex-specific migration patterns of hawksbill turtles breeding at Mona Island, Puerto Rico. Endang Species Res 4:85-94

Warner DA, Shine R (2008) The adaptive significance of temperature-dependent sex determination in a reptile. Nature 451:566-568

Wibbels T (1999) Diagnosing the sex of sea turtles in foraging habitats. In: Eckert KL, Bjorndal KA, Abreu-Grobois FA, Donnelly M (eds) Research and management techniques for the conservation of sea turtles. Publ No. 4. IUCN/SSC Marine Turtle Specialist Group, Washington, DC, p 139-143

Wibbels T (2003) Critical approaches to sex determination in sea turtles. In: Lutz PL, Musick JA, Wyneken J (eds) The biology of sea turtles, Book 2. CRC Press, Boca Raton, FL, p 103-134

Wibbels TA, Owens DW, Morris YA, Amoss MSJ (1987) Sexing techniques and sex ratios for immature loggerhead sea turtles captured along the Atlantic coast of the United States. In: Witzell WN (ed) Ecology of East Florida sea turtles. Proc Cape Canaveral Florida Sea Turtle Workshop, Book 53. US Department of Commerce, NOAA, Miami, FL, p 65-74

> Wibbels T, Balazs GH, Owens DW, Amoss MS Jr (1993) Sex ratio of immature green turtles inhabiting the Hawaiian Archipelago. J Herpetol 27:327-329

Witherington B, Hirama S, Hardy R (2012) Young sea turtles of the pelagic Sargassum-dominated drift community: habitat use, population density, and threats. Mar Ecol Prog Ser 463:1-22

Witt MJ, McGowan A, Blumenthal JM, Broderick AC and others (2010a) Inferring vertical and horizontal movements of juvenile marine turtles from time-depth recorders. Aquat Biol 8:169-177

Witt MJ, Hawkes LA, Godfrey MH, Godley BJ, Broderick AC (2010b) Predicting the impacts of climate change on a globally distributed species: the case of the loggerhead turtle. J Exp Biol 213:901-911

Wright LI, Fuller WJ, Godley BJ, McGowan A, Tregenza T, Broderick AC (2012a) Reconstruction of paternal genotypes over multiple breeding seasons reveals male green turtles do not breed annually. Mol Ecol 21:3625-3635

Wright LI, Stokes KL, Fuller WJ, Godley BJ and others (2012b) Turtle mating patterns buffer against disruptive effects of climate change. Proc R Soc B Biol Sci 279: 2122-2127 doi:10.1098/rspb.2011.2285

Yntema C, Mrosovsky N (1980) Sexual differentiation in hatchling loggerheads (Caretta caretta) incubated at different controlled temperatures. Herpetologica 36:33-36

Yntema CL, Mrosovsky N (1982) Critical periods and pivotal temperatures for sexual differentiation in loggerhead sea turtles. Can J Zool 60:1012-1016

Submitted: May 29, 2012; Accepted: August 29, 2012

Proofs received from author(s): November 9, 2012 